\section{EREM 73/3}

Journal of Environmental Research, Engineering and Management Vol. 73 / No. 3 / 2017 pp. $7-20$ DOI 10.5755/j01.erem.73.3.19116 C Kaunas University of Technology
Organisational Culture Towards Quality Management Practices Considering Pro-ecological View

Received 2017/09

Accepted after revision 2017/09

\title{
Organisational Culture
}

Towards Quality Management Practices Considering Pro-ecological View

\section{Eglè Staniškienè, Živilè Stankevičiūtè}

School of Economics and Business, Kaunas University of Technology, Gedimino st. 50, Lithuania

\section{Joana Ramanauskaitè}

School of Economics and Business, Kaunas University of Technology, Gedimino st. 50, Lithuania AB Kauno grūdai, H. and O. Minkovskiu st. 63, LT-46550 Kaunas, Lithuania

Corresponding author: egle.staniskiene@ktu.lt

School of Economics and Business, Kaunas University of Technology, Gedimino st. 50, Lithuania

The number of organisations putting the issue of quality management practices (QMP) on strategic agenda has been growing in the past years, although the implementation of QMP is not always easy. The importance of organisational culture as a link in quality management is discussed. However, the majority of existing studies do not fully address the employees' pro-ecological view. To bridge this gap, the present study aims at revealing the organisational culture best suited for implementation of quality management practices considering a pro-ecological view of employees. Quantitative research was carried out in a Lithuanian agricultural organisation. Validated instruments were used to design an instrument measuring organisational culture, quality management practices and a pro-ecological view of employees. The findings reveal a correlation between developmental, group, and rational cultures and QMP. The surveyed organisation has integrated culture of development and group cultures. The study shows that the organisation already applies some of the QMP, which makes it easier for further implementation of quality management practices and systems. Previous studies have revealed a relation between environmental awareness and organisational culture. The present study resulted in no significant correlation between a pro-ecological view and organisational culture or QMP. A broader research sample might exhibit different results.

Keywords: Quality, organisational culture, quality management practices, pro-ecological view. 


\section{Introduction}

The roots of quality management systems lie in the concept of total quality management (TQM). Dahlgaard and Dahlgaard-Park (2006) define TQM as a company culture characterised by increased customer satisfaction through continuous improvement, in which all employees actively participate. Brown (2014) highlights that the basic premise is that you cannot facilitate learning, innovation and sustain excellence if you do not adopt an appropriate paradigm. Innovative organisations have an understanding of the importance of quality management systems as the essential assumptions for improving performance and granting success (Juškys and Ruževičius, 2010).

In search of the best understanding of quality management, organisations must address their organisational culture. Gimenez-Espin et al. (2012) argue that organisational culture is one of the most important variables in the success or failure of TQM implementation. Even though scientists agree to the impact of organisational culture on the TQM, Haffar et al. (2013) remark that the mechanism through which an organisations' culture comes to have an impact on TQM implementation has not been adequately addressed.

It is important that each member of the organisation strive to become involved in the organisation's activities and the processes of its improvement, i.e., to be ready for change. Many scholars have claimed that quality management $(\mathrm{QM})$ requires an organisational culture transformation to commitment to total customer satisfaction through continuous improvement (Alotaibi et al., 2013, Wu, 2015).

A pro-ecological view is considered as a supporting factor in implementation of QMP. Previous studies have revealed that managers are confronted with environmental issues. The ability of organisations to manage their environmental performance is an important issue for companies. The employees' pro-ecological view could be the driver for organisations not only to deal with ecological challenges but also to manage their performances. Some scholars investigate the external fit of QM with the environment (Naor et al., 2008). Eco-thinking is considered a positive factor toward implementing quality management practices.
Though the problem is not addressed excessively, it is clear that maintaining order and leading sustainable life have an effect on the working environment.

The aim of this study is to reveal the organisational culture best suited for implementation of QMP considering the employees' pro-ecological view.

\section{Organisational culture towards implementation of quality management practices}

Perception and application of QMP are essential for the success of quality management systems. Flynn et al. (1995) categorise 7 quality practices into 2 groups: infrastructure (top management support, workforce management, supplier involvement and customer involvement) and core (quality information, process management and product design). The infrastructure practices pertain to behavioural attributes of quality management, whereas the core practices relate to technical aspects (Naor et al., 2008). Appropriate implementation of QMP in an organisation allows taking actions and seeking certification of a quality management system, introduction of a quality management standard, or simply improving the performance of a company by analysing and clarifying ongoing processes.

An important assumption of a modern organisation is the understanding of growing sustainability problems. Egri and Herman (2000) identified the importance of environmental values in the formation of future leaders' visions and the orientation of their work towards environmental change. Some of the values required for companies to implement quality practices are also key values in environmental practices, such as efficient use of resources (Bandehnezhad et al., 2012). Thus, there is a close connection between ecological values and quality practices (Sánchez-Medina and Díaz-Pichardo, 2017). Testa et al. (2014) remark that the EMAS Regulations and the ISO 14001 are the main international documents enabling companies to implement the EMS and receive a certificate 
of production processes. Differences between these systems were highlighted by Neugebauer (2012), who discovered different external pressure sources for both standards: the choice to use the ISO 14001 standard is mostly derived from external stakeholders, and the appliance of EMAS is conditional on internal organisation motivation. Testa et al. (2014) argue that the EMAS Regulations set out stricter requirements for external communication than ISO 14001.

Researchers examine both positive and negative aspects of the implementation of quality management systems. According to Beer (2003), quality changes are a long-term process that requires major cultural changes. Naor et al. (2008) support Beer's statement that most of the quality improvement tests fail due to the lack of attention paid to the discovery of organisational culture and QMP.

Implementation of QMP is a long process that requires continuous improvement of an organisation and the effort of all its members. Scientific literature presents a rather unanimous view that organisational culture influences the implementation of QMP. Eco-friendly employees also have a positive impact on the organisation's improvement processes.

Organisations are made up of different groups of people, creating different subcultures. Organisations are characterised as supporting common values and seeking a common understanding that forms the enterprise as a united entity that includes all members of an organisation; however, the subcultures created by organisations can disrupt the unity (Kujala et al., 2016). QMP can facilitate the orientation of all organisational subcultures for the formation of a common culture acceptable to the targeted management of the company.

Organisational culture can be as an explanatory variable that allows one organisation to be distinguished from another and affects the way the organisation operates and consequently plays an important role in many facets of the organisation (Zu et al., 2010). The organisational culture can be explained empirically based on the competing values framework (CVF), developed by Quinn and other contributors (Quinn, 1988, Quinn and Kimberly, 1984, Quinn and Rohrbaugh, 1981, 1983, Quinn and McGrath, 1985, Zu et al., 2010).
The CVF is intended to provide a comprehensive understanding of the culture of an organisation and to explain how the organisation's cultural structures are linked to compliance, motivation, leadership, decision-making, efficiency and organisational formalities. The theory of competing values model is based upon comprehensive empirical data from well-organised organisations based on performance criteria and indicators (Patapas and Labenskytè, 2011).

The CVF consists of 2 main axes, which indicate different value orientation. The control-flexibility axis (vertical) indicates the organisation's attitude towards change and stability (Zu et al., 2010). The internal-external axis (horizontal) expresses the orientation of the company towards the organisation and its integration and external orientation and competitiveness (Zu et al., 2010). These 2 axes represent the 4 types of organisational cultures: team (group) culture, development culture, hierarchical culture and rational culture. This is shown in Figure 1.

It is important to assume that the quadrants of the model of competing values framework of the organisational culture, as outlined in Figure 1, are ideals. In general, organisations tend to have mixed cultures

\section{Fig. 1}

The competing values framework of organisational culture (Cameron and Freeman, 1991, Denison and Spreitzer, 1991, Zu et al., 2010

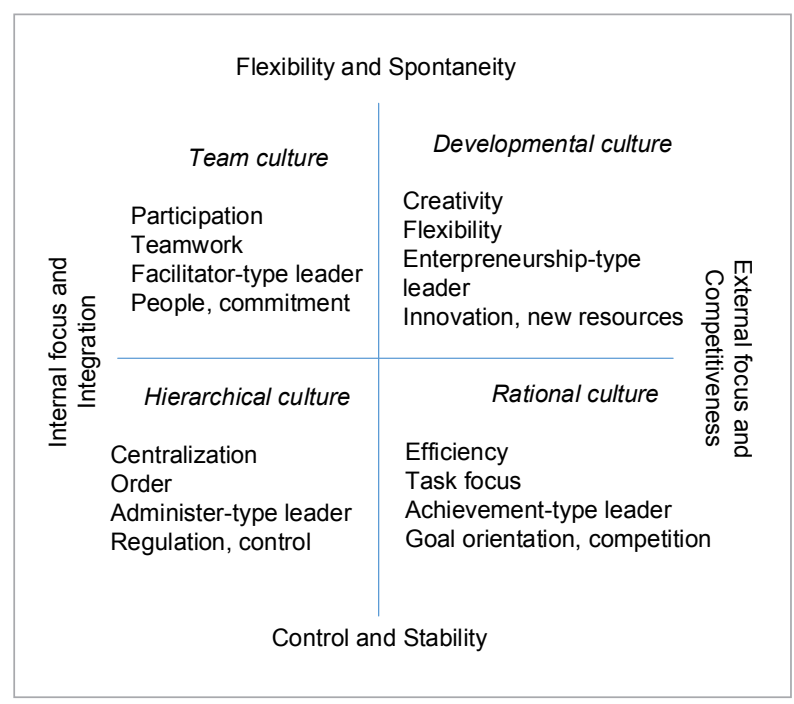


with a more pronounced influence and attributes of one of these cultures.

Most researchers agree that different organisational culture affects organisational processes differently. The importance of leadership, communication between different departments and engagement are emphasised. Cameron and Quinn (1999) point out that competing values that assist an organisation in implementing quality management systems can be found in each culture: empowerment, teamwork, employee involvement, human resource development and open communication are the characteristics of team culture; development of new standards, product development, continuous improvement, customer orientation and discovery of new solutions represent (development) culture; error detection, process control, systemic problem solving, application of quality tools and measurements refer to hierarchical culture; measurement of consumer needs, productivity gains, involvement of suppliers and customers, increasing competitiveness and development of cooperation characterise market (rational) culture (Gimenez-Espin et al., 2012). These values in organisations can be intertwined and manifest independently of the prevailing culture.

An organisation dominated by team culture emphasises the importance of morality and strives to achieve long-term gains from a focus on human resource development (Haffar et al., 2013, Zu et al., 2010). Naor et al. (2008) emphasize that organisations with team culture provide their members with freedom of expression in product development, process management and responsibility for results. Such organisations are focused on collectivism through teamwork. Effective process management is achieved through rapid decision-making and informal procedures. Iran et al. (2002) and Detert et al. (2000) believe that the team (clan) culture is the most suitable for implementing quality management system programmes and quality practices. For successful quality practices, organisational culture needs to be flexible and, if necessary, to change and become oriented towards customer, top management support, employee involvement and internal orientation (Page and Curry, 2000, Gimenez-Espin et al., 2012).
The development culture emphasises the high level of flexibility and change that depends on the external environment (Zu et al., 2010). Gimenez-Espin et al. (2012) and Haffar et al. (2013) define the development culture as adhocratic. Adhocratic culture encourages continuous innovation, higher education, autonomy, motivation and availability of relevant information on the workforce (Gimenez-Espin et al., 2012, Lo, 2002). Innovative culture is essential for the involvement of customers and suppliers, since there is a need to tolerate mistakes made to gain new knowledge (Naor et al., 2008, Naveh and Erez, 2004). Forecasting and outsourcing of customer needs, continuous innovation, access to information and flexibility are the main characteristics inherent in the development (adhocratic) culture (Douglas and Judge, 2001, Gimenez-Espin et al., 2012). Some research studies indicate that organisations with a developmental (adhocratic) culture and well-established quality systems achieve better results (Lagrosen and Lagrosen, 2003). Most researchers agree that developmental culture has a positive effect on implementation of QMP.

Rational culture, as seen in Figure 1, is outward-looking, but it emphasises control and stability that is geared towards competitiveness and the attainment of goals (Zu et al., 2010). Gimenez-Espin et al. (2012) and Haffar et al. (2013) identify rational culture as a market culture. Rational organisations are looking for external perspectives that could be used to differentiate their position from the point of view of competitors. According to these researchers, this is a result-driven ethos, where morality and personal education are less valued by leaders who are more interested in doing work and ensuring profitability.

Rational (market) as well as hierarchical culture is characterised by a high level of bureaucracy. This culture emphasises the importance of control. This type of culture is considered to be less suitable for global quality management and successful use of quality practices (Mosadegh Rad, 2006). A negative connection between formalism/hierarchy and innovation has been found (Gimenez-Espin et al., 2012). Issues of morality and personal development are often taken as not important in rational organisations (Haffar et al., 2013, Zammut et al., 2000). 
Hierarchical culture is centred on the organisation's control and stability. This culture is characterised by integrity, internal efficiency and strict adherence to rules and regulations (Gimenez-Espin et al., 2012, Zu et al., 2010). Control and reporting mechanisms are seen as key success factors. Haffar et al. (2013) point to bureaucracy, complicated rules and rigid processes as descriptive of a hierarchical organisation.

Customer focus and continuous improvement are the most important characteristics of successful organisations and quality management systems; however, as most researchers point out, hierarchical culture does not have these features (Espina-Gimenez et al., 2012, Jabnoun and Sedrani, 2005). The studies reveal support for the opinion that the organisation's hierarchy does not lead to successful TQM implementation (Gimenez-Espino et al., 2012, Kumar and Shankar, 2007, Walumbwa and Lawber, 2003) and a high bureaucracy cultures discourage TQM for the missing guidance to the client (Gimenez -Espin et al., 2012, Haffar et al., 2013, Lagrosen and Lagrosen, 2003).

Team (group) and development (adhocratic) cultures are the most favourable for implementing universal quality management and QMP (Haffar et al., 2013). The researchers point out that hierarchical and market (rational) cultures are least suitable for the application of universal quality management and quality practices.

The assessment and prioritization of a team organisation shows that the organisation has a trust relationship between team members, thus creating a common practice (Lai, 2016). Such relationships encourage innovation as most new and adaptive ideas emerge from groups of collaborative individuals (Lloyd-Walker et al., 2014).

The anticipated negative control-oriented crop effect has been approved. Market and hierarchical cultures had a negative influence on quality management systems (Gimenez-Espin et al., 2012). Researchers have found that the most appropriate quality management was the mixed system of team (clan) and developmental (adhocratic) cultures. Excessive focus on controls prevents the TQM from requiring employees to be given greater freedom and responsibility in order to integrate and continuously improve the number of errors (Gimenez-Espin et al., 2012).

\section{Employees' pro-ecological view towards implementation of quality management practices}

Green management plays an increasing role in the modern business world. This is due to increasing consumer needs. Such eco-management practices are assessed by focusing on the organisation's ability to manage development towards the improvement of eco-efficiency, which leads to improved performance of the company to ensure products, processes and eco-innovations (Roy and Khastagir, 2016).

In light of the observations made in the literature analysis, it becomes clear that certain values may have a greater or lesser impact on organisational culture and the successful implementation of QMP. Zwetsloot et al. (2004) argue that it is no longer employee satisfaction that matters, but respect, credibility and fairness of management, resulting in employee dedication and higher performance levels, especially with respect to productivity and creativity. Employees with more space to be creative can begin to think globally while performing their daily tasks, i.e. how their actions affect other people, nature etc.

Dunlap and Van Liere (2000) have developed their own eco-scale divided into 5 groups outlining the following: the reality of limits to grow; antianthropocentrism; the fragility of nature's balance; rejection of exemptionalism; and the possibility of an ecocrisis. The new ecological paradigm (NEP) created by Dunlap and Van Liere was designed to change the belief that people are isolated from environmental constraints on the technology used, taking into account the current human relationship with the environment (Foster, 2012). By adopting this concept, people think of themselves as a part of nature that does not have any extraordinary qualities that can distinguish them from other living and dead creatures that coexist on earth. Employees who realise that from an ecological point of view they share the same land as their colleagues will be more likely to cooperate and share their experience in pursuit of a common goal.

EMAS emphasises environmental values and sustainability. Zwetsloot and Van Marrewijk (2004) point out 
that socially responsible organisations are transparent in reporting their impact on people, the planet and profits, which is especially relevant for EMAS. Papagiannakis and Lioukas (2012) also highlight that organisational environmental responsibility expresses the depth of organisations' responses to natural environmental problems. The environmental approach is increasingly highlighted, as well as the prognosis of the individual's environmental practices, such as sorting and recycling, saving and waste management. Actively encouraged employees with a positive environmental impact can have a surprising effect on the environment through other factors, such as the impact on activities of an organisation to which they belong (Papagiannakis and Lioukas 2012). Marshall et al. (2005) discovered individual and other characteristics (managerial attitudes and subjective norms) that have a strong positive connection to the organisation's environmental performance.

Environmental values are important for improving the living environment and business processes. Some of the key business outcomes are those that organisations achieve through quality practices such as reducing inventory costs, increasing flexibility, improving productivity and increasing consumer satisfaction. These results are the 'driving factors' of increasing profitability, reputation and market share - the key indicator of business achievement (Sánchez-Medina and Díaz-Pichardo, 2017). Quality is an integral part of business success.

High-level enterprises are conducive to the implementation of a high level of environmental protection in the event that they are focused on pollution prevention (Claver et al., 2007, Wagner 2005). This demonstrates the importance of focusing on the ecological aspects of processes, the consumption of energy and raw materials, rather than reducing pollution at the end of the process by putting filters into end-pipe technologies.

Organisations with environment-oriented shareholders develop environment-friendly strategies that reduce the environmental impact, which has a positive effect on eco-competitiveness related to market, internal, profitability and risk factors (Wagner and Schaltegger, 2004). Besides, less polluting organisations are more likely to adapt to advanced strategies that reduce emissions and include other measures to promote sustainability and excellence. Ecological activities of an organisation stimulate the search for and develop new resources (Lopez-Gamero et al., 2009).

Organisations are likely to be more inclined to develop the skills needed to be ecologically sustainable and to follow sustainability principles if they follow the principles of universal quality management and have acquired qualitative skills (Curkovic et al., 2000). In addition, most authors note that the quality and ecological requirements of organisations are constantly increasing. This is associated with ever-changing environmental conditions (Wiengarten and $\mathrm{Pa}-$ gell, 2012).

Integrated management systems combine both quality management and environmental management practices. By applying these systems to address quality and environmental issues, an integrated management system can improve the ecological aspects of the organisation - the main orientation of the organisation towards a systematic solution of environmental problems (Siva et al., 2016, Von Ahsen and Funck, 2001).

Some changes may affect employees' satisfaction with their work or unintentionally alter organizational rules. The most appropriate type of culture for any organisation is one that embodies the characteristics that help organisations to be effective and competitive in the environment in which they operate (Daft, 2012). As most modern organisations operate in a rapidly changing environment, adaptation of organisations is considered to be a key aspect in the deployment of high-quality systems (Kontoghiorghes, 2016).

It can be stated that values describe the organisational culture favourable to the implementation of QMP. The theory of uncertainty requires organisations to achieve external coherence with the environment and the internal consistency of the elements of the organisational structure in order to improve performance (Naor et al., 2008). Figure 2 presents a theoretical model developed according to the analysed scientific literature. It enables the organisation to use the prevailing culture more effectively in case of implementation of QMP.

Most researchers agree that team culture has a positive influence on the implementation of quality management systems and the application of QMP. 


\section{Fig. 2}

Model of factors influencing the implementation of environmental protection and quality management systems

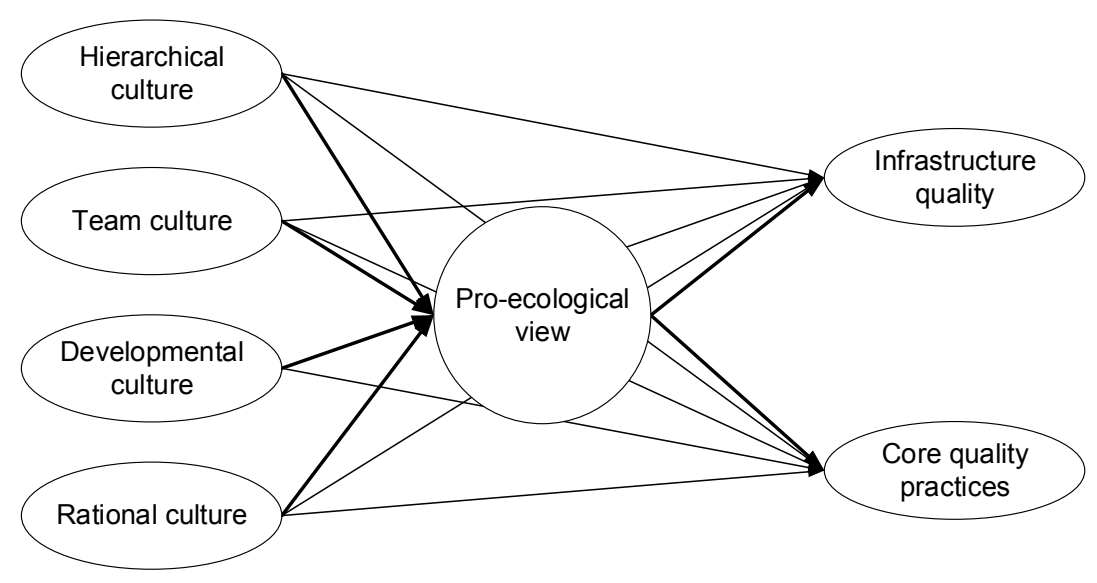

The following hypotheses are provided in the paper:

$\mathrm{H} 1$ : The culture of development and teamwork is conducive to the application of QMP.

$\mathrm{H} 2$ : The employee pro-ecological view is a stimulating factor in the implementation of organisational culture and QMP.

H3: Organisational culture influences the implementation of QMP.

\section{Methods}

The survey was conducted in a Lithuanian agriculture organisation. Around 750 employees work in this organisation. Most of these employees take administrative positions. Due to automatization of production, the company has a relatively small number of employees. The organisation has a number of distant subdivisions with employees not able to be interviewed in a written survey. The survey was conducted with participants of different age groups, gender, duration of service and working time.

The survey received 82 survey responses. Most participants were more than 40 years old (36\%), mainly women (62\%). More respondents have been working in the organisation longer than 5 years (54\%). A minority of survey participants have subordinates (27\%).

The instrument chosen for quantitative research was developed using 2 different validated instruments chosen from the researches of Naor et al. (2008) and Dunlap and Van Liere (2000). The survey instrument consisted of two parts: the organisational management and process scale and the new ecological paradigm (NEP) scale.

Organisation and process control scales, compiled by Naor et al. (2008), are divided into 3 distinct scales:

1 Questions 1 to 16 refer to organisational culture types. This part is intended to identify the prevailing type of organisational culture: group, hierarchical, developmental or rational.

2 Questions 17 to 31 address the management of internal qualitative processes. This section determines which level of management 'lowers' the basic quality requirements: support for top managers, workforce management, involvement of customers or suppliers.

3 Questions 32 to 45 refer to the main methods of quality assurance. Three methods used to assess key quality assurance techniques are quality information, process control, product development. 
Organisation and process control scales use 7-point Likert scales. Responses range from 'strongly agree' to 'strongly disagree'.

In order to assess the environmental performance of workers, the new ecological paradigm scale, based on a 15-point scale, was used (Dunlap et al. 2000). Recognition that human activities are changing the ecosystems on which our existence is dependent and growing acknowledgment of the necessity of achieving more sustainable forms of development give trust to suggestions that people are in the midst of a fundamental re-evaluation of the underlying worldview that has guided their relationship to the physical environment (Dunlap et al. 2000).Besides, the positive environmental provisions of employees can facilitate the application of QMP in organisations. The
NEP scale used 5-point Likert scale with responses ranging from 'strongly agree' to 'strongly disagree'.

Table 1 presents the overall validity of the research. The characteristic is made up of reliability and factor analysis data.

Questionnaires were distributed to 105 employees, of which 82 responses ( $80.95 \%$ return rate) were received. The survey data were transmitted to be electronically processed by IBM SPSS Statistics 22 and the Microsoft Excel 2013 programmes. Bivariate correlations were calculated in order to understand the connections between the statements of different scales. The internal consistency and reliability of the questionnaire developed and piloted for this study was rested with Cronbach's alpha resulting in a level of statistical significance of $a=0.05$.

\section{Table 1}

Instrument validity

\begin{tabular}{l|c|c|c|c}
\hline \multicolumn{1}{c|}{ Scale } & Statements & Factor loadings & \% variance explained & Cronbach's alpha \\
\hline Hierarchical culture & 2 & 3 & 4 & 5 \\
\hline Team culture & 4 & $0.169-0.882$ & 18.50 & 0.734 \\
\hline Rational culture & 4 & $0.680-0.825$ & 22.54 & 0.796 \\
\hline Developmental culture & 4 & $0.524-0.713$ & 21.77 & 0.748 \\
\hline Top management support & 4 & $0.654-0.839$ & 21.77 & 0.791 \\
\hline Workforce management & 5 & $0.684-0.850$ & 24.22 & 0.863 \\
\hline Supplier involvement & 3 & $0.371-0.820$ & 11.76 & 0.699 \\
\hline Customer involvement & 3 & $0.805-0.855$ & 15.64 & 0.817 \\
\hline Quality information on processes & 4 & $0.647-0.844$ & 17.73 & 0.811 \\
\hline Process management & 5 & $0.208-0.686$ & 22.54 & 19.58 \\
\hline Product design & 4 & $0.291-0.762$ & 14.12 & 0.723 \\
\hline
\end{tabular}

\section{Results and discussion}

Table 2 presents the mean score for TQM practices implementation, NEP and organisational culture types in the surveyed organisation. Additionally, it was found that the organisational cultures tend to have a mixture of the 4 culture types of the competing values framework instrument. However, team culture and developmental culture were the dominant organisational culture types. 


\section{Table 2}

The mean score of TQM, NEP and organisational culture types

\begin{tabular}{l|c|c}
\hline \multicolumn{1}{c|}{1} & Mean & Std. Deviation \\
\hline Hierarchical culture & 3.667 & 3 \\
\hline Team culture & 5.188 & 1.378 \\
\hline Rational culture & 4.061 & 1.214 \\
\hline Developmental culture & 4.930 & 1.842 \\
\hline NEP & 3.508 & .385 \\
\hline Infrastructure quality & 5.040 & .822 \\
\hline Core quality practices & 5.430 & .705 \\
\hline
\end{tabular}

The surveyed organisation is dominated by a combination of team (mean=5.188) and developmental (mean=4.930) cultures, which is considered to be extremely conducive to the introduction of QMP, especially for ongoing development, sharing of opinions and cooperation.

Bivariate correlations were examined in order to determine the associations between the culture of the organisation and the overall indicator of QMP:

hierarchical culture showed no correlation with QMP;

team culture and QMP showed a weak correlation -

$r=0.457, p<0.01$;

rational culture and QMP showed a weak correlation $r=0.474, p<0.01$;

developmental culture and QMP showed a moderate correlation $-r=0.568, p<0.01$.

As hierarchical culture in this study is not related to QMP, further relationship between these components will not be considered.

Team culture is characterised by weak correlation with QMP. Team culture correlates with the support of top managers $(r=0.429, p<0.01)$, customer involvement $(r=0.399, p<0.01)$ and quality information on processes $(r=0.432, p<0.01)$. The strongest link is between team culture and quality information practice. This reflects the fact that members of the organization achieve higher results in teamwork by sharing and having the access to the information.
Rational culture and QMP have a somewhat stronger relationship. Rational culture correlates with top management support $(r=0.538, p<0.01)$, customer involvement $(r=0.458, p<0.01)$ and quality information on processes $(r=0.515, p<0.01)$. The most likely result of customer orientation is the achievement of goals and profitability of an organisation that has rational culture, which is achieved by satisfying customers.

Developmental culture is one of the predominant cultures in the surveyed organisation. This culture correlates with the top managers support $(r=0.574$, $p<0.01)$, customer involvement $(r=0.483, p<0.01)$, quality information on processes $(r=0.576, p<0.01)$, process management $(r=0.401, p<0.01)$ and product development $(r=0.383, p<0.01)$. Quality information on processes, proper process management, support for this information and product development are critical to developmental culture as it pushes for continuous improvement, customer focus and proper management of human resources.

Respondents tend to be eco-conscious, as the mean of NEP scale statements is 3.508 . Such result could be due to the complex formulation of statements, the negative wording of some statements, as well as the eco-thinking, which has not yet been fully integrated into Lithuanian culture. Descriptive statistics of NEP scale results are demonstrated in Table 3.

It is clear that the respondents do not see the threat of limited growth capabilities as a serious threat. Overall understanding of growing challenges of ecology problems is seen in the attitude and survey results of employees.

\section{Table 3}

Descriptive statistics of NEP scale results

\begin{tabular}{l|c|c}
\hline & Mean & Std. Deviation \\
\hline 1 & 2 & 3 \\
\hline The reality of limits to growth & 2.877 & 0.674 \\
\hline Antianthropocentrism & 3.733 & 0.704 \\
\hline The fragility of nature's balance & 3.846 & 0.557 \\
\hline Rejection of exemptionalism & 3.272 & 0.535 \\
\hline The possibility of an eco-crisis & 3.831 & 0.683 \\
\hline
\end{tabular}


The correlation between the NEP scale and the organisational cultural has not been proved statistically by this study. There is also no correlation between eco-thinking and demographic data. However, to summarise the results of the scientific literature analysis and the fact that the significance of the Spearman correlation is quite close to 0.000 , it can be stated that ecology is inversely proportional to the length of work experience in the organisation $(r=-0.254, p<0.05)$, as well as women are more susceptible to having ecological preferences than men $(r=0.232, p<0.05)$. The main reason for this is that younger employees tend to use terms such as ecology, sustainability, etc.

Figure 3 shows the theoretical model with the calculated correlation coefficients. The NEP scale showed no relation to organisational cultures or QMP, but, according to the scientific literature analysis, the relevance and impact cannot be completely ruled out.

The obtained correlation coefficients are weak to moderate due to the small sample of respondents and the different scale sensitivity of organisational culture, QMP and the new ecological paradigm.
The development of the employees' pro-ecological view and behaviour would save resources, create more sustainable products and promote positive advertising. A good example of a sustainable organisation would improve and secure a strong market position. Promoting the involvement of suppliers would ensure timely production, less unplanned shutdowns and more accurate calculation of raw material demand. This would not only improve organisations' performance, help to apply quality management practices, ensure stability, but also contribute to solving environmental problems.

The research presented is suitable for further improvement and adaptation. It would be possible to confirm the strong correlation between quality management practices, organisational culture, and the employee pro-ecological view by surveying a larger sample of respondents. An organisational culture survey could be expanded to evaluate the organisation's values. A broader sample would also contribute to stronger results in the calculation of bonds between organisational culture, pro-ecological view and QMP.

\section{Fig. 3}

Model of factors influencing the implementation of environmental protection and quality management systems regarding study results

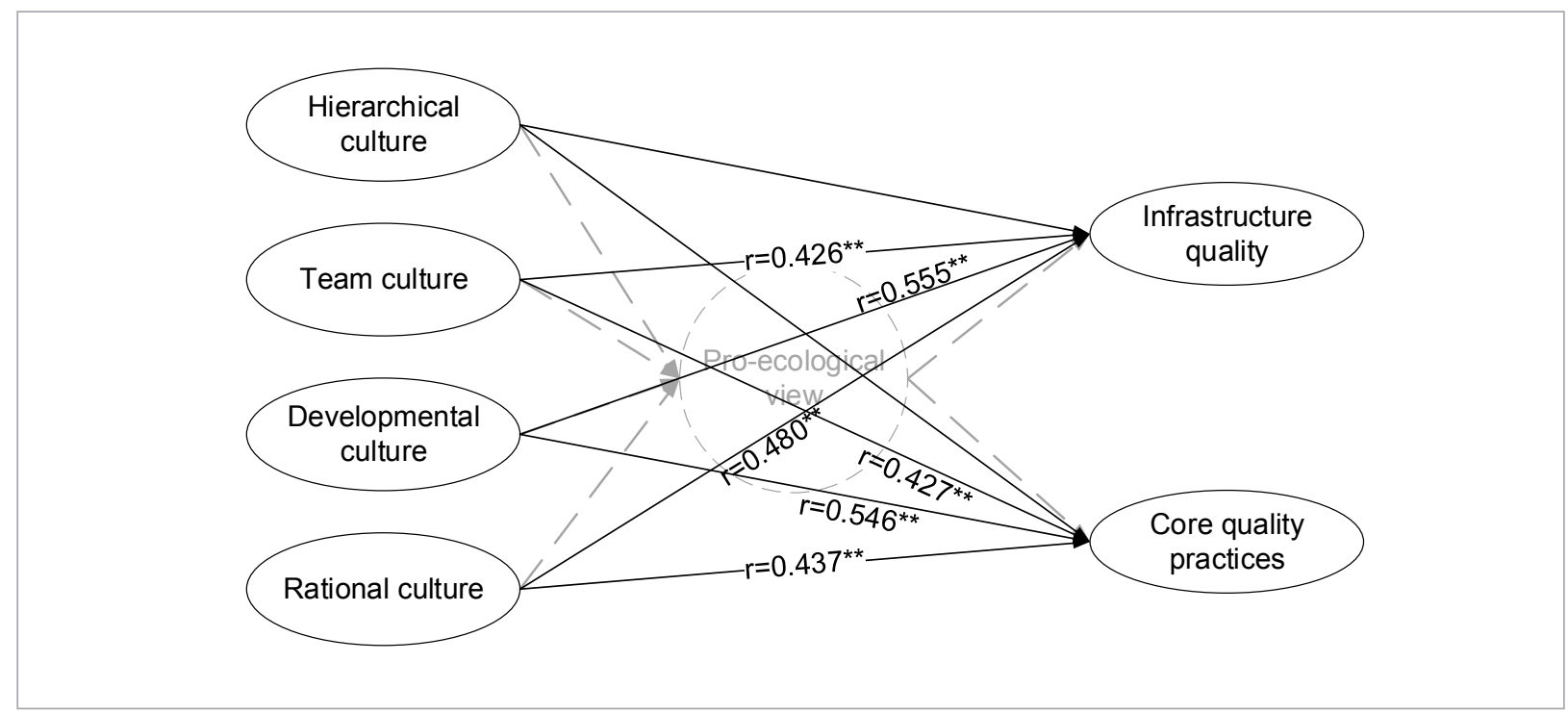

Note: ${ }^{* *}$ Correlation is significant at the 0.01 level (2-tailed). 


\section{Conclusions}

Organisations often encounter problems when implementing QMP. Scientific literature provides insights that certain cultures are more appropriate for TQM implementation than others. This is due to different leadership styles, i.e., the types of leadership, organisation's activities and traditions. Hierarchical organisational culture, defined by clear requirements, structures and subordinate QMP is not appropriate due to possible 'strangulation' in bureaucracy. Rational/market culture is also considered to be inappropriate by most researchers due to one-sided setting of goals and orientation to profit. It fosters competitiveness among employees. As a result, QMP may not work because there is no sincere cooperation between colleagues.

Team and developmental cultural models are the most appropriate for QMP implementation among the four distinct cultural types (hierarchical, team, rational and developmental). Their interconnection encourages cooperation, innovation, employee empowerment and motivation, customer orientation, employees' involvement in organisational processes, development and improvement of new products. Constant improvement is promoted particularly in developmental culture - a necessity for universal quality management. This practice can also be applied to team culture by means of motivating employees and bringing them together to work for a common goal, team building and work efficiency. These findings are similar to those of Naor et al. (2008), Gimenez-Espin et al. (2012), Haffar et al. (2013) and Zu et al. (2010).

The relevance of team and development cultures for the development of QMP highlighted by the analysis of scientific literature was confirmed by the survey results. The study revealed that the organisation integrates a combination of these cultures, with stronger characteristics of team culture. The organisation also applies QMP: manpower management, customer involvement in the product development process and process management, based on procedural quality information. Other practices, in particular, involvement of suppliers, support of managers and development of new products, could be improved. According to the data obtained, the theoretical model, adapted to the applicability of QMP, has been adapted to the suitability of organisational culture. The correlation between organisational cultures and QMP was calculated. There is no correlation between hierarchical culture and QMP. Team, rational and development cultures have a medium correlation with QMP. No significant correlations were found between eco-thinking and QMP, but, according to scientific literature, these studies can be further developed with higher sampling because logical dependencies between these scales can be seen.

\section{References}

Arimura, T. H., Darnall, N., Ganguli, R. \& Katayama, H. (2016). The effect of ISO 14001 on environmental performance: Resolving equivocal findings. Journal of environmental management, 166, 556-566. https://doi.org/10.1016/j.jenvman.2015.10.032

Alotaibi, F., Zien Yusoff, R., \& Islam, R. (2013). Relationship between total quality management practices and contractors competitiveness. American Journal of Applied Sciences, 10 (3): 247-252. https://doi.org/10.3844/ajassp.2013.247.252

Bandehnezhad, M., Zailani, S. \& Fernando, Y., (2012). An empirical study on the contribution of lean practices to environmental performance of the manufacturing firms in northern region of
Malaysia. Int. J. Value Chain Manag. 6 (2), 144-168. https://doi. org/10.1504/IJVCM.2012.048379

Beer, M. (2003). Why TQM programs do not persist: The role of management quality and implications for leading a TQM transformation. Decision Sciences, 34(4), 623-642. https://doi. org/10.1111/j.1540-5414.2003.02640.x

Brown, A. (2014). Organisational paradigms and sustainability in excellence. International Journal of Quality and Service Sciences, 6(2/3), 181. http://eserv.uum.edu. $\mathrm{my} /$ docview $/ 1651162227$ ? accountid=42599. https: $/ /$ doi. org/10.1108/IJQSS-02-2014-0020 
Burton, R. M., Lauridsen, J. \& Obel, B. (2004). The impact of organizational climate and strategic fit on firm performance. Human Resource Management, 43(1), 67-82. https://doi. org/10.1002/hrm.20003

Cameron, K.S., \& Quinn, R.E. (1999). Diagnosing and changing organisational culture: Based on the competing values framework. Reading, MA: Addison-Wesley.

Claver, E., López, M.D., Molina, J.F. \& Tarí, J.J. (2007). Environmental management and firm performance: A case study, Journal of Environmental Management, Volume 84, Issue 4, Pages 606-619, ISSN 0301-4797, https://doi.org/10.1016/j. jenvman.2006.09.012.

Curkovic, S., Melnyk, S.A., Handfield, R.B. \& Calantone, R.J., (2000). Investigating the linkage between TQM and environmentally responsibly manufacturing. IIEE Transactions on Engineering Management 47 (4), 444-464. https://doi. org/10.1109/17.895340

Daft, R. (2012). Organization theory and design (11th ed.). Mason, $\mathrm{OH}$ : South-Western.

Dahlgaard, J. J. \& Dahlgaard-Park, S.M. (2006). Lean production, six sigma quality, TQM and company culture. The TQM magazine, 18(3), 263-281. https://doi.org/10.1108/09544780610659998

Detert, J.R., Schroeder, R.G. \& Muriel, J., (2000). A framework for linking culture and improvement initiatives in organizations. Academy of Management Review 25 (4), 850-863.

Douglas, T.J. \& Judge, W.Q. (2001). TQM implementation and competitive advantage: The role of structural control and exploration. Academy of Management Journal, 44(1), 158-169. https://doi.org/10.2307/3069343

Dunlap R.E. \& Van Liere K. D. (2000). Measuring endoserment of the ecological paradigm: a revised NEP scale. Journal of Social Issues. 425 - 442 p. https://doi.org/10.1111/0022-4537.00176

Egri, C.P. \& Herman, S., (2000). Leadership in the North American environmental sector: values, leadership styles, and contexts of environmental leaders and their organizations. Acad. Manag. J. 43 (4), 571-604. https://doi.org/10.2307/1556356

Foster, J. B. (2012). The planetary rift and the new human exemptionalism: A political-economic critique of ecological modernization theory. Organization \& Environment, 25(3), 211-237. https://doi.org/10.1177/1086026612459964

Gimenez-Espin, J.A., Jimenez-Jimenez, D. \& Martinez-Costa, M. (2012). Organisational culture for TQM. TQM \& Business Excellence, iFirst, 1-15, https://doi.org/10.1080/14783363.2012. 707409

Haffar, M., Al-Karaghouli, W. \& Ghoneim, A., (2013) The mediating effect of individual readiness for change in the relationship between organisational culture and TQM implementation, TQM
\& Business Excellence, 24:5-6, 693-706, https://doi.org/10.108 $0 / 14783363.2013 .791112$

Irani, Z., Beskese, A. \& Love, P.E.D., (2004). TQM and corporate culture: constructs of organizational excellence. Technovation 24, 643-650. https://doi.org/10.1016/S0166-4972(02)00128-1

Jabnoun, N., \& Sedrani, K. (2005). TQM, culture, and performance in UAE manufacturing firms. The Quality Management Journal, 12(4), 8-20.

Juškys, A., \& Ruževičius, J. (2010). Aplinkosaugos vadybos sistemu diegimo motyvacija ir naudingumas: Vokietijos aukštuju mokyklų patirties studija. Verslo ir teisės aktualijos, 5, 57-74. https://doi.org/10.5200/1822-9530.2010.02

Karassin, O. \& Bar-Haim, A. (2016). Multilevel corporate environmental responsibility. Journal of Environmental Management, 183, 110-120. https://doi.org/10.1016/j.jenvman.2016.08.051

Kontoghiorghes, C. (2016). Linking high performance organizational culture and talent management: satisfaction/motivation and organizational commitment as mediators. The International Journal of Human Resource Management, 27(16), 18331853. https://doi.org/10.1080/09585192.2015.1075572

Kujala, J., Lehtimäki, H. \& Pučètaitè, R. (2016). Trust and distrust constructing unity and fragmentation of organisational culture. Journal of Business Ethics, 139(4), 701-716. https:// doi.org/10.1007/s10551-015-2915-7

Lagrosen, S. \& Lagrosen, Y. (2003). Quality configurations: A contingency approach to quality management. The International Journal of Quality \& Reliability Management, 20(6/7), 759773. https://doi.org/10.1108/02656710310491203

Lai, K. S., Yusof, N. A. \& Kamal, E. M. (2016). Organizational culture of the architectural firm: a case in a developing country. International Journal of Construction Management, 16(3), 197 208. https://doi.org/10.1080/15623599.2016.1166545

Lloyd-Walker, B. M., Mills, A. J., \& Walker, D. H. (2014). Enabling construction innovation: the role of a no-blame culture as a collaboration behavioural driver in project alliances. Construction Management and Economics, 32(3), 229-245. https://doi.org/1 $0.1080 / 01446193.2014 .892629$

Lo, T.Y. (2002). Quality culture: A product of motivation within organization. Managerial Auditing Journal, 17(5), 272-276. https://doi.org/10.1108/02686900210429704

López-Gamero, M. D., Molina-Azorín, J. F. \& Claver-Cortes, E. (2009). The whole relationship between environmental variables and firm performance: Competitive advantage and firm resources as mediator variables. Journal of environmental management, 90(10), 3110-3121. http://www.sciencedirect. com/science/article/pii/S030147970900156X. https://doi. org/10.1016/j.jenvman.2009.05.007 
Marshall, R. S., Cordano, M. \& Silverman, M. (2005). Exploring individual and institutional drivers of proactive environmentalism in the US wine industry. Business Strategy and the Environment, 14(2), 92. https://doi.org/10.1002/bse.433

Mosadegh Rad, A.M. (2006). The impact of organizational culture on the successful implementation of TQM. The TQM Magazine, 18(6), 606-625. https://doi.org/10.1108/09544780610707101

Naor, M., Goldstein, S. M., Linderman, K. W. \& Schroeder, R. G. (2008). The role of culture as driver of quality management and performance: Infrastructure versus core quality practices. Decision Sciences, 39(4), 671-702. https://doi.org/10.1111/j.15405915.2008.00208.x

Naveh, E. \& Erez, M. (2004). Innovation and attention to detail in the quality improvement paradigm. Management Science, 50(11), 1576-1586. https://doi.org/10.1287/mnsc.1040.0272

Neugebauer, F. (2012). EMAS and ISO 14001 in the German industry - complements or substitutes? Journal of Cleaner Production, Volume 37, Pages 249-256. https://doi.org/10.1016/j. jclepro.2012.07.021

Oliveira, J. A., Oliveira, O. J., Ometto, A. R., Ferraudo, A. S. ir Salgado, M. H. (2016). Environmental Management System ISO 14001 factors for promoting the adoption of cleaner production practices. Journal of Cleaner Production, 133, 1384-1394. https://doi.org/10.1016/j.jclepro.2016.06.013

Page, R. \& Curry, A. (2000). TQM - A holistic view. The international bi-monthly for TQM. The TQM Magazine, 12(1), 11-17. https://doi.org/10.1108/09544780010287159

Papagiannakis, G. \& Lioukas, S. (2012). Values, attitudes and perceptions of managers as predictors of corporate environmental responsiveness. Journal of Environmental Management, 100, 41-51. https://doi.org/10.1016/j.jenvman.2012.01.023

Patapas, A. \& Labenskytè, G., (2011). Organizacinès kultūros ir vertybiu tyrimas $\mathrm{N}$ apskrities valstybinèje mokesčių inspekcijoje. Viešoji politika ir administravimas, T. 10, Nr. 4, 589-603.

Quinn, R.E. \& McGrath, M.R., (1985). The transformation of organizational cultures: a competing values perspective. Organizational Culture. Sage Publications Inc, Beverly Hills, CA, pp. 315-334.

Quinn, R.E., (1988). Beyond Rational Management: Mastering the Paradoxes and Competing Demands of High Performance. Jossey-Bass, San Francisco, CA.

Quinn, R.E. \& Kimberly, J.R., (1984). Paradox, planning, and perseverance: guidelines for managerial practice. In: Quinn, R.E., Kimberly, J.R. (Eds.), Managing Organizational Transitions. Irwin, Homewood, IL, pp. 295-313.

Quinn, R.E. \& Rohrbaugh, J., (1981). A competing values approach to organizational effectiveness. Public Productivity Review 5 (2), 122-140. https://doi.org/10.2307/3380029
REGULATION (EC) No 1221/2009 OF THE EUROPEAN PARLIAMENT AND OF THE COUNCIL of 25 November 2009 on the voluntary participation by organisations in a Community eco-management and audit scheme (EMAS), repealing Regulation (EC) No 761/2001 and Commission Decisions 2001/681/EC and 2006/193/EC

Roy, M. \& Khastagir, D. (2016). Exploring role of green management in enhancing organizational efficiency in petro-chemical industry in India. Journal of Cleaner Production, 121, 109-115. https://doi.org/10.1016/j.jclepro.2016.02.039

Sánchez-Medina, P. S. \& Díaz-Pichardo, R. (2017). Environmental pressure and quality practices in artisanal family businesses: The mediator role of environmental values, Journal of Cleaner Production, Volume 143, 145-158, ISSN 0959-6526. http://doi. org/10.1016/j.jclepro.2016.12.137.

Schein, E. H. (1992), Organizational culture and leadership (2nd ed.). San Francisco: Jossey-Bass.

Siva, V., Gremyr, I., Bergquist, B., Garvare, R., Zobel, T. \& Isaksson, R. (2016). The support of quality management to sustainable development: a literature review. Journal of Cleaner Production, 138, 148-157., http://www.sciencedirect.com/science/ article/pii/S095965261600038X. https://doi.org/10.1016/j. jclepro.2016.01.020

Testa, F., Rizzi, F., Daddi, T., Gusmerotti, N. M., Frey, M. \& Iraldo, F. (2014). EMAS and ISO 14001: The differences in effectively improving environmental performance. Journal of Cleaner Production, 68, 165-173. Elsevier Ltd. https://doi.org/10.1016/j. jclepro.2013.12.061

Von Ahsen, A. \& Funck, D. (2001). Integrated management systemsdopportunities and risks for corporate environmental protection. Corporate environmental strategy, 8(2), 165-176. https://doi.org/10.1016/S1066-7938(01)00089-6

Wagner, M. (2005). How to reconcile environmental and economic performance to improve corporate sustainability: corporate environmental strategies in the European paper industry. Journal of Environmental Management 76, 105-118. https:// doi.org/10.1016/j.jenvman.2004.11.021

Wagner, M. ir Schaltegger, S. (2004). The effect of corporate environmental strategy choice and environmental performance on competitiveness and economic performance: an empirical study of EU manufacturing. European Management Journal, 22(5), 557-572. https://doi.org/10.1016/j.emj.2004.09.013

Walumbwa, F. O. \& Lawber, J. J. (2003). Building effective organizations: Transformational leadership, collectivist orientation, work related attitudes and withdrawal behaviours in three emerging economics. Human Resources Management, 14(1), 3-14. https://doi.org/10.1080/0958519032000114219 
Wiengarten, F. \& Pagell, M. (2012). The importance of quality management for the success of environmental management initiatives. International Journal of Production Economics, 140(1), 407-415. https://doi.org/10.1016/j.jppe.2012.06.024

Wu, S. J., (2015), The impact of quality culture on quality management practices and performance in Chinese manufacturing firms, International Journal of Quality \& Reliability Management, Vol. 32 Iss 8 pp. 799-814. https://doi.org/10.1108/IJQRM-12-2013-0199
Zu, X., Robbins, T. L. \& Fredendall, L. D. (2010). Mapping the critical links between organizational culture and TQM/Six Sigma practices. International journal of production economics, 123(1), 86-106. https://doi.org/10.1016/j.ijpe.2009.07.009

Zwetsloot, G. I. M. \& Van Marrewijk, M. N. (2004). From quality to sustainability. Journal of Business Ethics, 55(2), 79-82. https:// doi.org/10.1007/s10551-004-1893-y

\section{Organizacijos kultūros tinkamumas kokybès vadybos praktikų diegimui atsižvelgiant į darbuotojų ekologines nuostatas}

\section{Eglè Staniškienè, Živilè Stankevičiūtè}

Kauno technologijos universitetas, Ekonomikos ir verslo fakultetas, Gedimino g. 50, Kaunas

\section{Joana Ramanauskaitè}

Kauno technologijos universitetas, Ekonomikos ir verslo fakultetas, Gedimino g. 50, Kaunas AB Kauno grūdai, H. ir O. Minkovskiu g. 63, LT-46550 Kaunas, Lietuva

Pastaraisiais metais daugeja organizaciju, kurios kokybès vadybos praktikas laiko strateginiu prioritetu, tačiau ju igyvendinimas nèra toks sèkmingas. Mokslineje literatūroje analizuojamas organizacijos kultūros vaidmuo igyvendinant kokybės vadybos praktikas. Tačiau dauguma atliktu tyrimų neanalizuoja, kaip darbuotoju ekologinès nuostatos veikia organizacijos kultūrą. Šio straipsnio tikslas - atskleisti organizacijos kultūrą, tinkamiausią kokybès vadybos praktiku taikymui ir diegimui atsižvelgiant i darbuotoju ekologines nuostatas. Darbuotoju ekologinès nuostatos yra laikomos vienu iš esminiu faktoriu, darančiu jtaką organizacijos kultūrai. Kiekybinio tyrimo instrumentas sudarytas remiantis validuotomis organizacijos kultūros bei darbuotoju ekologinių nuostatų tyrimų skalèmis. Kiekybinis tyrimas atliktas Lietuvos žemės ūkio organizacijoje. Apklausos rezultatais įrodytas ryšys tarp vystymosi, komandinès bei racionalios kultūru ir kokybès vadybos praktikų. Tirta organizacija pasižymi komandinès bei vystymosi kultūru derme. Taip pat organizacijoje yra taikomos kokybès vadybos praktikos. Statistiškai reikšmingo ryšio tarp darbuotoju ekologinių nuostatu bei kokybės vadybos praktikų nenustatyta. Atliekant tyrimą su didesne imtimi, šis ryšys galètų būti ịrodytas, nes mokslinèje literatūroje akcentuojama darbuotojų ekologinių nuostatu itaka organizacijos kultūrai.

Raktiniai žodžiai: kokybè, organizacinè kultūra, kokybės vadybos praktika, ekologinis požiūris. 